dog of glioscience also has a refreshingly prominent place), gap junctions, extracellular space and gliosis. The authors have, in general, covered their subject from classical times to the present day to represent an in-depth look at glial cells from the accumulated vision of numerous dedicated scientists. I would recommend the book not only to neuroscientists but also to anyone interested in examining the intricacies of specialized cells.

In the study of neurobiology, it seems that glial scientists initially had the harder task. While those studying neurons could point to an obvious function, and focused their attention largely on electrical activity, glial cells did not give up their roles so easily. Researchers had to construct ingenious theories about glial cell function on the basis of a wealth of anatomical and physiological studies. In doing so they may, in the end, have created a more holistic understanding of glial cells compared to neurons. Neuroglia is the culmination of nearly a century of work in the shadow of neurons, and, as far as domination by the neuron concept goes, this book, at a mighty seven pounds in weight, goes a long way to redressing the balance.

Sally Temple is in the Department of Pharmacology and Neuroscience, Albany Medical College, Albany, New York 12208, USA.

\section{Romantic ideals}

\section{Graham Farmelo}

The Myth of Scientific Literacy. By Morris Shamos. Rutgers University Press: 1995. Pp. 238. \$27.95.

TRYING to define scientific literacy is like trying to nail a pudding to a balloon. Should scientifically literate people be expected, unlike most scientists, to be familiar with every branch of science? If not, what facts should the scientific literati know? Should they understand the methods of scientific enquiry and how science is administered?

Although the concept of scientific literacy is infuriatingly imprecise, its promotion has become something of a cottage industry in the West. Indeed, few commentators can be heard actually opposing (or even questioning) attempts to improve what is generally known as the 'public understanding of science', another multiply ambiguous and unfortunate catchphrase. The overwhelming consensus among scientists and politicians is that the achievement of scientific literacy is an important strategic goal for countries that wish to compete in the new global economy. Yet it is by no means obvious that the aims of many advocates of science literacy are achievable or that this type of literacy is essential for the public good.

In this 238-page indictment of sloppy thinking about the public dimensions of science education, Morris Shamos addresses these issues, mainly in the context of his experience in the United States (although most of what he says applies to some extent to other Western countries, notably the United Kingdom). He suggests that it is a fallacy to assume that the achievement of scientific literacy in schools would necessarily lead to a corresponding effect among adults, who have never accepted that they need to know much about science. (You can hardly blame them: most successful people manage perfectly well without it.) His depressing conclusion is that the idea that a notable degree of scientific literacy is achievable among the US public is "little more than a romantic idea".

Shamos is an emeritus professor of physics at New York University and a respected veteran of a wide variety of science education projects in schools and universities. It must, therefore, have been a painfully cathartic experience for him to have written this critique of the arguments that he, or at least many of his colleagues, have used to justify their work over the past few decades. Although his tone is sweetly reasonable throughout, many of his fellow science educators will be shocked by the brutal candour of his analysis and unsettled by his blunt conclusions. For someone who apparently believes that he has spent most of his working life building and maintaining a house of cards, he is remarkably free of rancour and regret.

$\mathrm{He}$ assembles his case in a series of chapters that probe and question orthodox thinking about scientific literacy. After questioning whether there really is a crisis in science education, he considers the special nature of science (which he carefully distinguishes from technology and engineering) and reviews the history of initiatives in the public understanding of science. In the crux of the book, he then goes on to discuss the progress of the US 'science literacy movement', from the pioneering work of the philosopher and educator John Dewey in the early part of this century, to the drive for science literacy after the Second World War, the panic that followed the 1957 launch of the Soviet Sputnik and the current disquiet over high-school standards and public attitudes towards science. Despite a slew of well-intentioned educational projects, the proportion of Americans who might reasonably be considered to be scientifically literate is now no more than about six per cent.

Past failures of policy have led to some bizarre initiatives, notably by President George Bush, the 'Education President' as he wished to become known, who set the risibly optimistic target that US students would lead the world in achievement in science and mathematics by 2000 . Comments on its inevitable failure will no doubt be drowned by the millennial ballyhoo - if so, another opportunity to learn from impractical optimism about science education policy will have been wasted.

Shamos is in no doubt that the scientific literacy movement has failed - failed to be clear about what it wants to achieve, failed to set realistic targets and failed to make a significant impact even in its own wishy-washy terms. The clear implication is that vast sums of money have been frittered away on science literacy projects and that although rationality, intellectual rigour and self-criticism characterize good scientists, these qualities do not yet apply to most science educators. As one embarks on the section entitled "Do educational experiments ever fail?", one braces oneself for another Shamos onslaught. It duly arrives, with the expected pain.

Having wreaked havoc with the conventional agenda of scientific literacy, he does the decent thing and suggests another perspective, although without much enthusiasm. He suggests that we should define scientific literacy in terms of goals that just might be achievable: it might, for example, be possible to improve the public's awareness both of science and of what can be expected from it. Also, much more could be done to give laypeople a clearer, better-informed voice in the scientific enterprise. Shamos uses these and other ideas to suggest the basis of a new approach to the teaching of science to general (that is, non-science) students, suggestions that will affront the beleaguered hard-liners.

It is possible to carp at Shamos's pedestrian prose, his prolixity and his repetitiousness, but there is no denying that he has marshalled a formidable case against decades of muddled thinking about scientific literacy. No one concerned about the science education agenda can be indifferent to his arguments: some will reflect that they have a good deal of rethinking to do, others that they have a lot to answer for.

Graham Farmelo is at the Science Museum, Exhibition Road, London SW7 2DD, UK.

\section{New in paperback}

Einstein, History, and Other Passions: The Rebellion Against Science at the End of the Twentieth Century by Gerald Holton Addison-Wesley, \$14. A distinguished scientist and historian of science draws on the life and work of Einstein to examine the role of science in Western culture and argue for the necessity of reason. 